Article

\title{
Predicting the Saturated Hydraulic Conductivity of Clayey Soils and Clayey or Silty Sands
}

\author{
Stefania Bilardi ${ }^{1}\left(\mathbb{D}\right.$, Domenico Ielo $^{2}\left[\right.$ and Nicola Moraci ${ }^{1, *}$ (i) \\ 1 Department of Civil, Energy, Environmental and Materials Engineering, Mediterranea University of Reggio \\ Calabria, Via Graziella località Feo di Vito, 89124 Reggio Calabria, Italy; stefania.bilardi@unirc.it \\ 2 Office for the environment, Ministry of defence, 96011 Siracusa, Italy; ielod@marina.difesa.it \\ * Correspondence: nicola.moraci@unirc.it; Tel.: +39-09651692263
}

Received: 7 September 2020; Accepted: 29 September 2020; Published: 1 October 2020

\begin{abstract}
Predictive models able to provide a reliable estimate of hydraulic conductivity can be useful in various geotechnical applications. Since most of the existing predictive methods for saturated hydraulic conductivity estimation are valid only for a limited range of soils or can be applied under certain restrictive conditions, a new method applicable to clayey soils and clayey or silty sands having a wide range of values of soil index properties is proposed in this study. For this purpose, 329 saturated hydraulic conductivity values, obtained by laboratory tests carried out on different soils, were collected in a database and used to develop five equations using a multiple regression approach. Each equation correlates the hydraulic conductivity with one or more geotechnical parameters. An equation was developed that predicts, within an order of magnitude, the saturated hydraulic conductivity in the range from $1.2 \times 10^{-11}$ to $3.9 \times 10^{-6} \mathrm{~m} / \mathrm{s}$, based on simple geotechnical parameters (i.e., clay content, void ratio, plastic limit, and silt content).
\end{abstract}

Keywords: clay content; plastic limit; predictive model; silt content; void ratio

\section{Introduction}

Hydraulic conductivity in cohesive soils is an important design parameter in various geotechnical applications, for example, when these materials are used as construction materials (e.g., in landfill, barrier systems, in levees, in earth dams, or in slurry walls), or in the cases where a modelling of filtration processes is required for the design.

Predictive models, able to provide a reliable estimate of hydraulic conductivity, can be useful during the screening phase, in order to restrict the number of field or laboratory permeability tests to perform in the design (time consuming and sometimes expensive) and to facilitate the choice of the most suitable soil for the execution of the earth works. Moreover, the methods to predict permeability could be used in preliminary numerical analyses.

Permeability predictive methods are generally based on soil index properties that are simple to be obtained by economic and routine classification tests. For this purpose, the literature presents several methods that allow predicting the saturated hydraulic conductivity $\left(K_{\text {sat }}\right)$.

Predictive models can derive from empirical relationships, theoretical approaches such as capillary models and hydraulic radius theory [1] or from fractal models [2-4].

Different predictive methods for $K_{\text {sat }}$ determination of plastic soils, use porosity $(n)$, or void ratio (e), parameters related to grain size distribution (e.g., diameters corresponding to $10 \%$ and $50 \%$ passing in grain size distribution, $d_{10}, d_{50}, \%$ clay, or the specific surface) and Atterberg limits (e.g., liquid limit $w_{L}$ or plasticity index IP). The different predictive methods refer to intact or remolded (homogenized) plastic soils or to compacted plastic soils [1]. 
Since most of the existing predictive methods for saturated hydraulic conductivity estimation are valid only for a limited range of soils or can be applied under certain restrictive conditions, a new method applicable to clayey soils and clayey or silty sands is proposed in this study. For this purpose, reliable information available in literature providing grain size distribution curve (GSDC), porosity or void ratio, Atterberg limits, and saturated hydraulic conductivity of different plastic soils are collected in a database, and used to develop an equation able to provide a reliable estimate of the saturated hydraulic conductivity for a wide range of soils using a multiple regression approach. Five equations were developed; each one correlates the hydraulic conductivity with one or more geotechnical parameters.

\section{Existing Literature Methods to Predict $K_{\text {sat }}$}

In the following, a set of equations proposed in literature by different authors to predict the $K_{\text {sat }}$ value of plastic soils, are briefly summarized in chronological order.

The most widely used predictive method for $K_{\text {sat }}$ estimation of both plastic and non-plastic soils is the use of the Kozeny-Carman equation [5], derived by semiempirical and theoretical evaluations and expressed by Equation (1):

$$
K_{\text {sat }}=\frac{\gamma}{\mu} \frac{1}{\mathrm{C}} \frac{1}{\mathrm{~S}_{0}^{2}} \frac{\mathrm{e}^{3}}{(1+\mathrm{e})}
$$

where $\gamma$ and $\mu$ are the unit weight and the viscosity of fluid (when the permeant is water at $20^{\circ} \mathrm{C}$ $\gamma / \mu=9.933 \times 10^{4} \mathrm{~cm}^{-1} \cdot \mathrm{s}^{-1}$ ), $C$ is a constant which depends on the porous space geometry (generally a value equal to 5 is assumed), $S_{0}$ is the specific surface per unit volume of particles $\left(\mathrm{cm}^{-1}\right), e$ is the void ratio. The determination of the specific surface is the main difficulty for the Kozeny-Carman equation application. For sand the specific surface can be calculated from grain size distribution [6-8], for plastic clayey soils it can be obtained with analytical methods or empirical correlations [9,10].

The Kozeny-Carman equation can be used for most soils having a single porosity [11] and should not be used for compacted soils which present a dual porosity [12]. Primary porosity corresponds to the fine structure at the micron scale of solid particles, the secondary porosity is equivalent to the porosity between artificially formed clay clods, which corresponds to a macrostructure resulting from excavation, transport, handling, and remolding by field equipment [8]. $K_{\text {sat }}$ value in compacted soils is in large part influenced by this secondary porosity $[1,8]$.

Another method for $K_{\text {sat }}$ prediction was proposed by [13]. They proposed an experimental relationship, Equation (2), obtained by analysis of consolidation-test results:

$$
e=\left(0.01 \times I_{p}+0.05\right)\left(10+\log K_{s a t}\right)
$$

where Ip is the plasticity index (\%), $e$ is the void ratio, $K_{s a t}$ is expressed in $\mathrm{cm} / \mathrm{s}$.

For remolded clay, the authors of $[14,15]$ proposed Equation (3) for $K_{\text {sat }}$ prediction in m/s:

$$
K_{\text {sat }}=\frac{0.0174 I_{p}^{-4.29}}{(1+e)}\left[e-0.027\left(w_{p}-0.242 I_{p}\right)\right]
$$

where $e$ is the void ratio, $w_{p}$ is the plastic limit (\%), and $I_{p}$ is the plastic index (\%). The Equation (3) should be used with caution because it may predict negative $K_{\text {sat }}$ values [1].

According to [16], $K_{\text {sat }}$ values, determined in normally consolidated remolded clays, using Terzaghi's consolidation theory, can be predicted through Equation (4):

$$
K_{\text {sat }}=C\left(\frac{e^{x}}{1+e}\right)
$$


where $K_{\text {sat }}$ is expressed in $\mathrm{m} / \mathrm{s}, e$ is the void ratio, $x$ is equal to about 5 (or in a range of 3.97-6.39 according to [17]), and $C$ is given by Equation (5):

$$
C=0.00104 I_{p}^{-5.2}
$$

where $I_{p}$ is the plastic index (\%).

The authors of [18] proposed the correlation expressed by Equation (6) for predict $K_{\text {sat }}$ in m/s knowing the void ratio $(e)$ and the liquid limit $\left(w_{L}\right.$ in $\left.\%\right)$. The experimental values of $K_{\text {sat }}$ were determined in sand-bentonite mixtures $\left(w_{L}>50 \%\right)$ through oedometer tests using Terzaghi's consolidation theory.

$$
\log K_{\text {sat }}=\frac{e-0.0535 w_{L}-5.286}{0.0063 w_{L}+0.2516}
$$

For $K_{\text {sat }}$ prediction, the authors of [10] proposed the correlation expressed by Equation (7) derived from the Kozeny-Carman equation. The equation was derived using results taken from the literature or obtained by the authors. The tests for $K_{\text {sat }}$ determination were conducted on reconstituted (remolded) specimens under constant or falling head conditions, using rigid-wall permeameters and triaxial cells.

$$
K_{s a t}=C_{P} \frac{\gamma_{w}}{\mu_{w}} \frac{e^{3+x}}{1+e} \frac{1}{\rho_{s}^{2} w_{L}^{2 \chi}}
$$

$K_{s a t}$ is expressed in $\mathrm{cm} / \mathrm{s}, C_{P}=5.6 \mathrm{~g}^{2} / \mathrm{m}^{4}, \gamma_{w}$ is the unit weight of water and equal to $9.8 \mathrm{kN} / \mathrm{m}^{3}, \mu_{w}$ is the water dynamic viscosity equal to $10^{-3} \times \mathrm{Pa} \cdot \mathrm{s}, \chi=1.5, \rho_{s}$ is density of solid expressed in $\mathrm{g} / \mathrm{m}^{3}$, $w_{L}$ is the liquid limit expressed in \%, and the parameter $\chi$ is defined by Equation (8):

$$
x=7.7 w_{L}^{-0.15}-3
$$

this relation is valid for plastic/cohesive (clayey) soils with $2.5 \times 10^{-11} \mathrm{~cm} / \mathrm{s} \leq K \leq 3.8 \times 10^{-6} \mathrm{~cm} / \mathrm{s}(0.29$ $\leq e \leq 5.96 ; 2.61 \leq G_{S}$ (specific gravity of the solid particles) $\leq 2.87 ; 20 \% \leq w_{L} \leq 495 \%$ ).

Examining in detail the Kozeny-Carman equation [1], the authors of [8] proposed Equation (9) which can be used for any soil, either plastic or non-plastic:

$$
\log \left(K_{s a t}\right)=0.5+\log \left(\frac{e^{3}}{G_{S}^{2} S_{S}^{2}(1+e)}\right)
$$

$K_{s a t}$ is expressed in $\mathrm{m} / \mathrm{s}, S_{S}$ is the specific surface expressed in $\mathrm{m}^{2} / \mathrm{kg}$ and $G_{S}$, the specific gravity, is dimensionless. For non-plastic soil $S_{S}\left(\mathrm{~m}^{2} / \mathrm{g}\right)$ can be determined by Equation (10) [8] when $w_{L}$ is lower than $110 \%$ :

$$
\frac{1}{S_{S}}=\frac{1.3513}{w_{L}}-0.0089
$$

The authors of [19] proposed the following equation:

$$
K_{\text {sat }}=7.2 \times 10^{-4} C_{F}^{-2}
$$

where $C_{F}$ is the clay content expressed in relative units and $K_{s a t}$ in $\mathrm{m} /$ day.

In [20], the authors proposed the following equation:

$$
K_{\text {sat }}=\frac{6.31 \times 10^{-7}}{\left(I_{p}-8.74 p\right)^{3.03}} e^{2.66\left(I_{p}-8.74 p\right)^{0.234}}
$$

where $K_{\text {sat }}$ is expressed in $\mathrm{m} / \mathrm{s}$ and $p$ is the percentage of clay minerals in the soil divided by 100 . This formula was derived knowing the hydraulic conductivity of five specimens, of expanding and non-expanding clays, determined in the laboratory using the falling-head test in an oedometer 
consolidation cell. Equation (12) is valid for fine-grained soils that contain non-swelling or limited-swelling clay minerals.

In [21,22], the authors proposed to evaluate $K_{\text {sat }}$ from the Kozeny-Carman equation (Equation (1)) determining the overall soil specific surface per unit volume of particles $S_{0}$ combining the contribution of the plastic clayey fraction $(d<2 \mu \mathrm{m})$ and that of the coarse fraction $(d>2 \mu \mathrm{m})$ as expressed by Equation (13).

$$
S_{0}=\frac{\left(S_{0, d>2 \mu m} \times f_{d>2 \mu m}+S_{0, d<2 \mu m} \times f_{d<2 \mu m}\right)}{f_{d>2 \mu m}+f_{d<2 \mu m}}
$$

where $S_{0, d>2 \mu m}$ is the specific surface of the non-plastic fraction of soil, whereas the $S_{0, d<2 \mu m}$ is the specific surface of the plastic clayey fraction, the $f_{d>2 \mu m}$ and $f_{d<2 \mu m}$ are the related weight fraction corresponding to the diameters greater and lower of $2 \mu \mathrm{m}$ [21]. Regarding the specific surface of the non-plastic fraction $(d>2 \mu \mathrm{m})$ of soil $\left(S_{0}\right)$ it can be determined through the method of [23] expressed by Equation (14):

$$
S_{0}=\frac{6}{D_{e f f}}
$$

where $D_{\text {eff }}$ is the representative diameter expressed by Equation (15):

$$
D_{\text {eff }}=\frac{100 \%}{\sum \frac{f_{i}}{D_{a v e, i}}}
$$

$f_{i}$ is the particles weight fraction, expressed in percentage, between two sieves of subsequent sieving. $D_{a v e, i}$ is the average diameter between the two considered sieves which can be calculated through Equation (16):

$$
D_{\mathrm{ave}, \mathrm{i}}=D_{l, i}^{0.404} \times D_{s, i}^{0.595}
$$

$D_{l, i}$ and $D_{s, i}$ are the diameters of the larger and smaller between the two considered sieves.

Regarding the specific surface of the plastic fraction $(d<2 \mu \mathrm{m})$ of soil it can be determined through Equation (10).

Table 1 summarizes the types of soils to which the methods above described can be applied and the possible limitations or conditions of validity.

Table 1. Types of soils and limitations of predictive methods for $K_{\text {sat }}$ estimation.

\begin{tabular}{ccc}
\hline Equations & Type of Soil & Limitations or Conditions of Validity \\
\hline 2 & Clay & - \\
3 & Remolded clay & May predict negative $K_{\text {sat }}$ values \\
4 & Normally consolidated remolded clay & x can vary in a range of $3.97-6.39$ \\
6 & Clay & $w_{L} 50 \%$ \\
& & $2.5 \times 10^{-11} \mathrm{~cm} / \mathrm{s} K_{s a t} \leq 3.8 \times 10^{-6} \mathrm{~cm} / \mathrm{s}$ \\
7 & Plastic soils & $0.29 \leq e \leq 5.96$ \\
& & $2.61 \leq G_{s} \leq 2.87$ \\
9 & Clay & $20 \% \leq w_{L} \leq 495 \%$ \\
11 & Sandy-clay soils & $w_{L}<110 \%$ \\
12 & Clay & - \\
1 and 13 & Clayey and silty-sandy soils & $1 \times 10^{-11} \mathrm{~m} / \mathrm{s} \leq K_{\text {sat }} \leq 5 \times 10^{-6} \mathrm{~m} / \mathrm{s}$ \\
\hline
\end{tabular}

\section{3. $K_{\text {sat }}$ Database from Literature Review}

From literature review, 329 saturated hydraulic conductivity values, determined by laboratory tests $[17,21,24-29]$, were collected. The main geotechnical characteristics of the soils studied by different authors are shown in Table 2. 
Table 2. Main geotechnical characteristics of tested soils [17,21,24-29].

\begin{tabular}{cccccccc}
\hline Reference & Numberof Tests & $e(-)$ & $\boldsymbol{I}_{\boldsymbol{P}}(\mathbf{\%})$ & $w_{L}(\mathbf{\%})$ & $\boldsymbol{C}_{\boldsymbol{F}}(\mathbf{\%})$ & $\boldsymbol{S}_{\boldsymbol{F}}(\mathbf{\%})$ & $\boldsymbol{K}_{\text {sat }}(\mathrm{m} / \mathbf{s})$ \\
\hline$[24]$ & 9 & $0.6-1.8$ & 38 & 68 & 80 & 20 & $3.8 \times 10^{-11}-1.1 \times 10^{-9}$ \\
{$[25]$} & 49 & $0.33-1.12$ & $2-62$ & $19-91$ & $14-75$ & $16-64$ & $2.7 \times 10^{-11}-2.7 \times 10^{-9}$ \\
{$[26]$} & 32 & $0.31-1.39$ & $11-46$ & $24-70$ & $16-65$ & $25-58$ & $1.3 \times 10^{-11}-3.3 \times 10^{-10}$ \\
{$[27]$} & 40 & $0.52-1.00$ & 12.5 & 17.5 & $2.7-5.7$ & $43-70$ & $1.2 \times 10^{-7}-3.9 \times 10^{-6}$ \\
{$[28,29]$} & 22 & $0.69-3.84$ & $18-71$ & $43-119$ & $47-77$ & $23-56$ & $1.3 \times 10^{-10}-4.0 \times 10^{-9}$ \\
{$[17]$} & 63 & $0.53-1.86$ & $9.5-25$ & $37-74$ & $5-35$ & $38-88$ & $1.2 \times 10^{-11}-6.8 \times 10^{-8}$ \\
{$[21]$} & 114 & $0.33-1.21$ & $5-45$ & $17-70$ & $5-67$ & $32-84$ & $1.2 \times 10^{-11}-9.3 \times 10^{-8}$ \\
\hline
\end{tabular}

$e=$ void ratio; $I_{P}=$ plastic index; $w_{L}=$ liquid limit; $C_{F}=$ clay fraction $(\mathrm{d}<0.002 \mathrm{~mm}) ; S_{F}=\operatorname{silt}$ fraction $(0.002<\mathrm{d}<$ $0.06 \mathrm{~mm}) ; K_{\text {sat }}=$ saturated hydraulic conductivity.

The clay tested by [24] was a grey marine plastic Champlain Sea clay from Louiseville (Quebec). IP is $38 \%, w_{L}$ is $68 \%$, and $C_{F}$ (percentage of particles smaller than $2 \mu \mathrm{m}$ ) is $80 \%$. The tests (No. 9) were carried out on an oedometer cell using the same specimen at different values of $e$, the hydraulic conductivity was determined through the falling-head permeability method.

The soils studied by [25] were compacted soil liners derived from landfills located in North America. Hydraulic conductivity was determined on "undisturbed" specimens (No. 49) taken using thin wall sampling (Shelby) tubes or as blocks. Hydraulic conductivity tests were performed in flexible-wall permeameters, rigid-wall Shelby tube permeameters, or consolidation cells equipped for direct measurement of hydraulic conductivity. The specimens have an $I_{p}$ between $2 \%$ and $62 \%$, a $w_{L}$ between $19 \%$ and $91 \%$, and $C_{F}$ between $14 \%$ and $75 \%$.

The authors of [26] studied 13 soils using three different compactive efforts (modified Proctor, according to ASTM D 1557, standard Proctor, according to ASTM D698, and reduced Proctor) and 32 specimens, compacted at a molding water content near to saturation, were considered for the database definition. The specimens have an $I_{p}$ between $11 \%$ and $46 \%$, a $w_{L}$ between $24 \%$ and $70 \%$, and $C_{F}$ between $16 \%$ and $65 \%$. The hydraulic conductivity of the specimens was determined by flexible-wall permeameters using the falling-head method according to ASTM D5084 procedure.

The 40 specimens studied by [27] were homogenized tailing from hard rock mines which can be identified, using the Unified Soil Classification System (USCS), as sandy silts of low plasticity (ML). The authors investigated four types of sulphide-free tailings obtained from three different sites. The soils have an $I P$ equal to $12.5 \%$, a $w_{L}$ of about $17.5 \%$, and $C_{F}$ between $2.7 \%$ and $5.7 \%$. The hydraulic conductivity was determined by means of rigid-wall permeameter using constant head and falling head conditions.

The 22 specimens investigated by the authors [28,29] were soils from Singapore, Bangkok, Ariake, Pusan, Tokyo, and London. The $\mathrm{I}_{\mathrm{p}}$ values ranges between $18 \%$ and $71 \%$, $w_{L}$ between $43 \%$ and $119 \%$, and $C_{F}$ between $47 \%$ and $77 \%$. Oedometer tests were carried out for hydraulic conductivity determination.

The 63 specimens investigated by [17] were remolded fine-grained soils having $I_{p}$ values between $9.5 \%$ and $25 \%, w_{L}$ between $37 \%$ and $74 \%$, and $C_{F}$ between $5 \%$ and $35 \%$. Hydraulic conductivity was determined by the falling head method in the standard one-dimensional consolidation apparatus.

The 114 specimens, studied by the authors of [21], were taken from the bottom and the walls of landfill, from road embankments, and from clay quarries of Italian sites. According to the USCS Classification (ASTM D 2487), the specimens considered by the authors are clayey sand and silty sand (SC-SM), silty clay (CL-ML), silt (ML), silt of high plasticity $(\mathrm{MH})$, and clay of high plasticity $(\mathrm{CH})$. The soils have $\mathrm{I}_{\mathrm{p}}$ between $5 \%$ and $45 \%$, $w_{L}$ between $17 \%$ and $70 \%$, and $C_{F}$ between $5 \%$ and $67 \%$. The hydraulic conductivity was mainly determined in triaxial test, according to the procedure ASTM D 5084-00 using the constant head method, on undisturbed specimens or remolded.

As can be observed from Table 2, the investigated soils have an $I_{P}$ between $2 \%$ and $71 \%, w_{L}$ between $17.5 \%$ and $119 \%, C_{F}$ between $2.7 \%$ and $80 \%$, and $S_{F}$ between $16 \%$ and $88 \%$. Therefore, a large range of soils was investigated, and it includes soils having low, medium, and high plasticity. 


\section{A New Predictive Method for the $K_{\text {sat }}$ of Fine Grained and Plastic Soils}

A new method able to predict $K_{\text {sat }}$ of fine grained and plastic soils for a range of values larger than that considered by most of the existing literature methods, is formulated in this study.

According to [1], a reliable predictive method should take into account the following information: (i) the porosity $n$ or the void ratio $e$; (ii) parameters referred to grain size distribution curve (GSDC) or specific surface of the solid grains; (iii) tests performed on fully saturated specimens; (iv) hydraulic conductivity of specimens determined through tests where the parasitic head losses can be excluded by using lateral manometers or proven to be negligible (for examples tests carried out in oedometer or triaxial tests for cohesive soils); (v) considering specimens that are not prone to internal erosion. Regarding the latter information, it is necessary to ascertain that the soil is not prone to internal erosion [30]. Regarding the soil grain size distribution, soils that have a grain size distribution that presents a concave upward curve, a gap inside the curve (gap-graded soils), or a broadly graded curve are generally considered to be internally unstable [31]. Different criteria can be used to determine the potential internal instability of a granular soil subjected to seepage [31-36].

Considering the information provided by [1] and the large number of experimental data contained in the created database (Table 2), five equations were developed in this regard for $K_{\text {sat }}$ prediction using a multiple regression approach.

Among the different variables available, some of these were selected, according to their greater influence on the hydraulic conductivity.

The variables predicting the experimental value of the saturated hydraulic conductivity were progressively added to the equations in order to obtain the best correlation between the predicted value $\left(K_{\text {pre }}\right)$ and the experimental one $\left(K_{\text {exp }}\right)$.

The reliability of each of the five proposed equations was checked through a "Correlation Index" $(C I)$, an index introduced by the authors and defined by Equation (17) which expresses how the predictive value of permeability $\left(K_{\text {pre }}\right)$ approaches the determined one $\left(K_{\exp }\right)$ :

$$
C I=\frac{\sum\left[\ln \left(\frac{K_{\text {exp }}}{K_{\text {pre }}}\right)\right]^{2}}{n}
$$

where $n$ is the number of soils. The best correlation is represented by a CI value tending to zero.

The equations proposed in this study for $K_{\text {sat }}$ prediction in $\mathrm{m} / \mathrm{s}$ are summarized below together with the CI values.

$$
\begin{gathered}
K_{\text {pre }}=7 \times 10^{-6} C_{F}^{-2.898}, C I=0.75 \\
K_{\text {pre }}=1.498 \times 10^{-5} C_{F}^{-2.898} \times e^{2.9015}, C I=0.46 \\
K_{\text {pre }}=8.58 \times 10^{-4} C_{F}^{-2.898} \times e^{2.9015} \times w_{p} w_{p}^{-1.377}, C I=0.33 \\
K_{\text {pre }}=3.38 \times 10^{-2} C_{F}^{-2.898} \times e^{2.9015} \times w_{p}^{-1.377} \times S_{F}^{-0.921}, C I=0.31 \\
K_{\text {pre }}=7.22 \times 10^{-4} C_{F}^{-2.898} \times S_{F}^{-1.43} \times w_{p}^{-0.567} \times \exp ^{0.0165 w_{L}}, C I=0.67
\end{gathered}
$$

The variables considered from Equation (18) to Equation (21) were taken using the following order: the clay content $\left(C_{F}\right)$ in percentage, the void ratio $(e)$, the plastic limit $\left(w_{p}\right)$ in percentage, and the silt fraction in percentage $\left(S_{F}\right)$.

The $C I$ values show as the $C_{F}$ contribution gives a good estimate of the $K_{\text {exp }}$ value (Equation (18)), the correlation significantly improves adding $e$ (Equation (19)) and slightly improves adding $w_{p}$ (Equation (20)) and $S_{F}$ (Equation (21)).

Another equation (Equation (22)) that considers only parameters obtained by economic and routine classification tests is proposed. The variables included are $C_{F}, S_{F}, w_{p}$, and $w_{L}$ in percentage (excluding $e$ ). 
The $C I$ value found for this equation (0.67) is greater than that obtained for Equation (21). This shows that $e$ is an important parameter influencing hydraulic conductivity value. In fact, its use allows reducing the $C I$ value and providing a more accurate assessment of the hydraulic conductivity.

The performance of the five Equations (18)-(22) is shown in Figures 1-5 where the $K_{\text {exp }}$ and $K_{\text {pre }}$ values $(\mathrm{m} / \mathrm{s})$ are compared for the 329 investigated specimens.

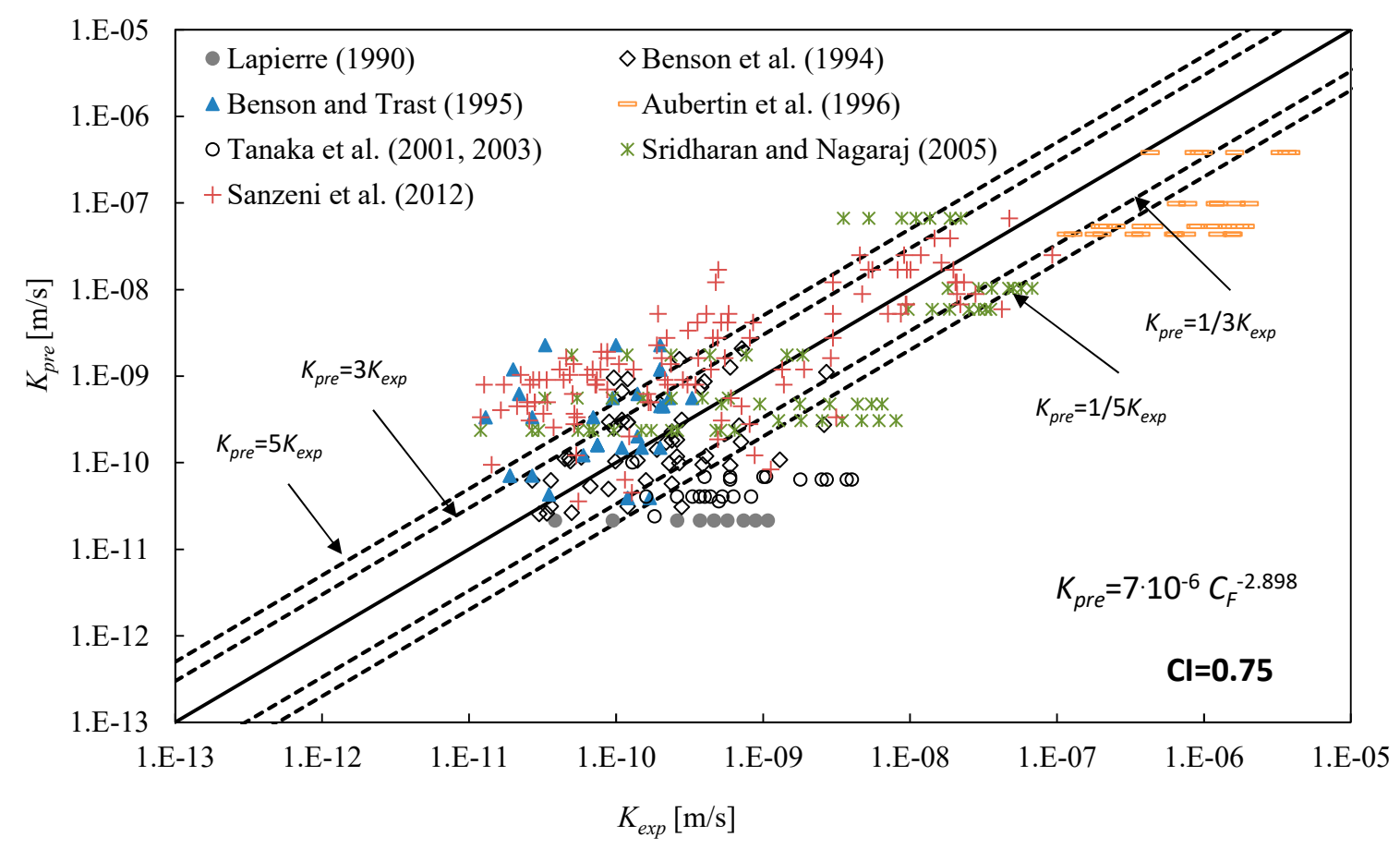

Figure 1. Experimental $\left(K_{\text {exp }}\right)$ and predicted value $\left(K_{\text {pre }}\right)$ of the saturated hydraulic conductivity as determined by Equation (18).

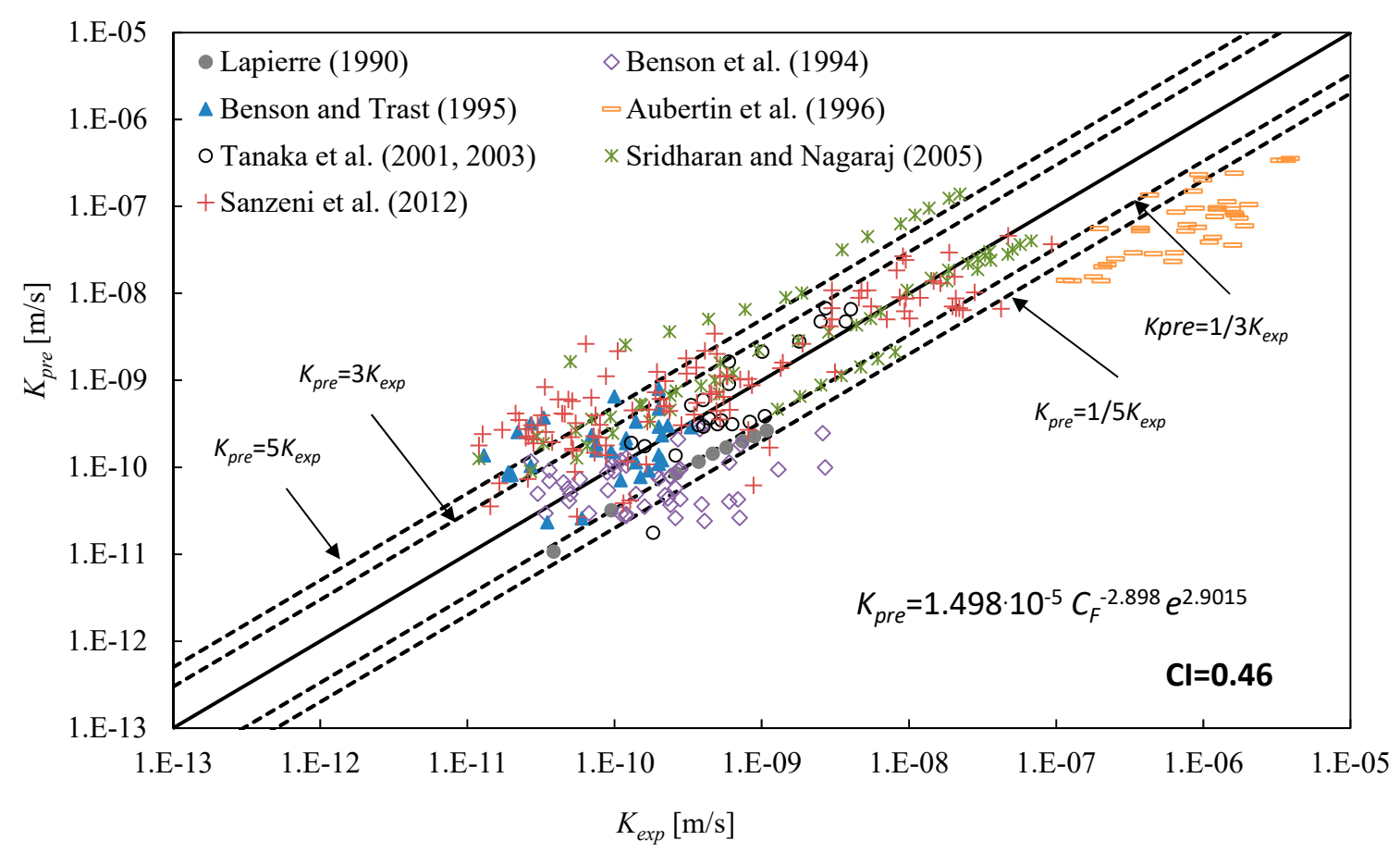

Figure 2. Experimental $\left(K_{\text {exp }}\right)$ and predicted value $\left(K_{\text {pre }}\right)$ of the saturated hydraulic conductivity as determined by Equation (19). 


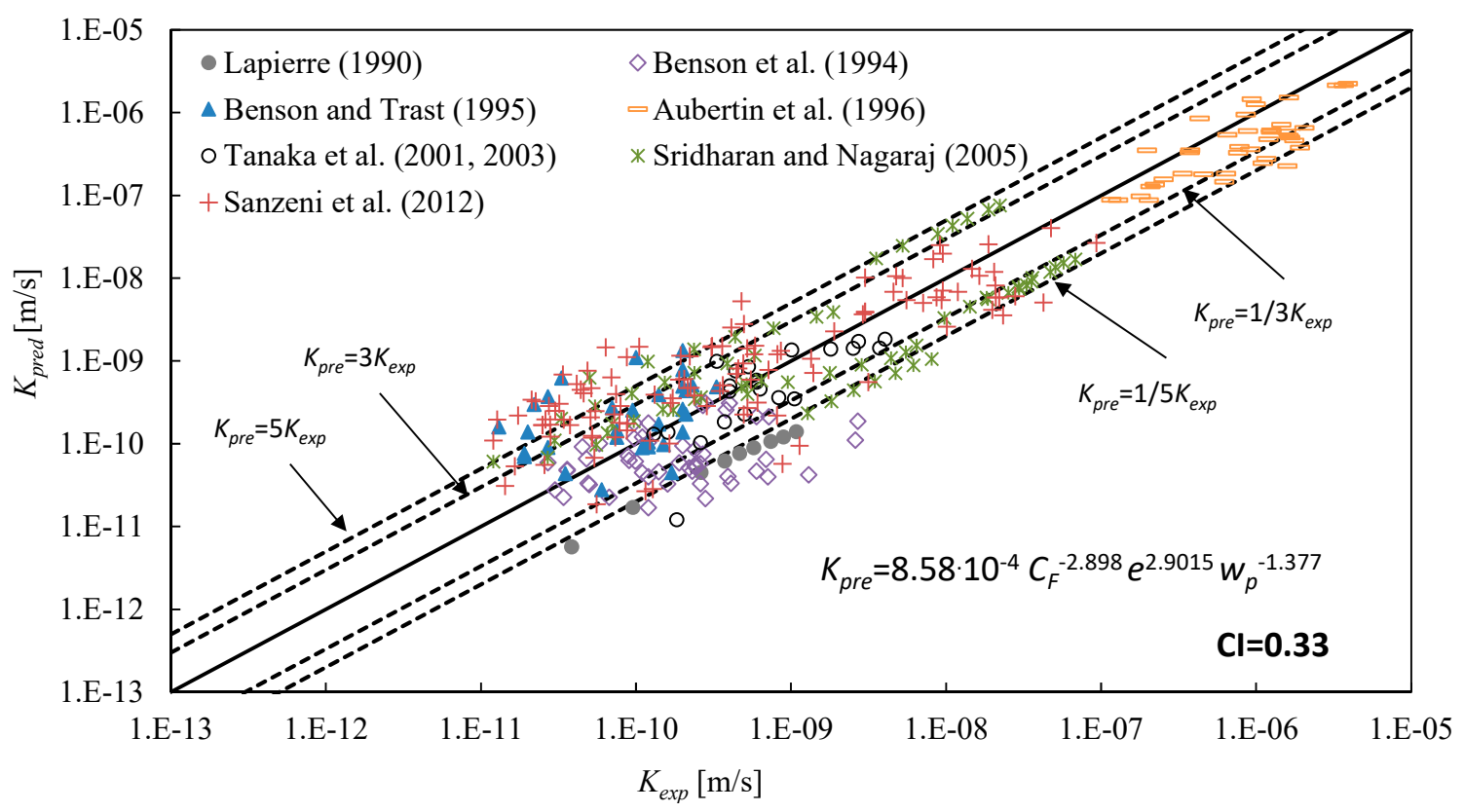

Figure 3. Experimental $\left(K_{\text {exp }}\right)$ and predicted value $\left(K_{\text {pre }}\right)$ of the saturated hydraulic conductivity as determined by Equation (20).

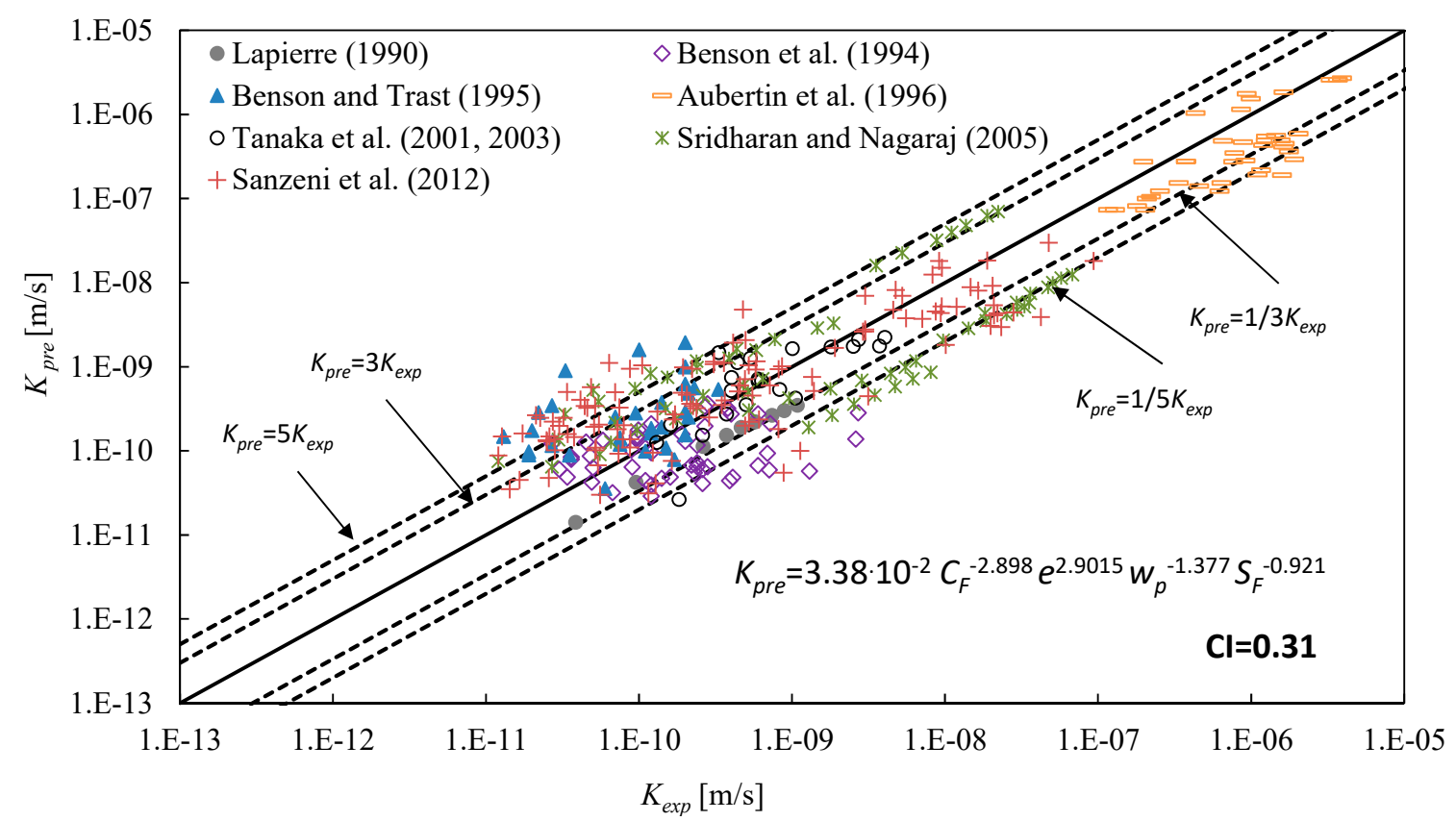

Figure 4. Experimental $\left(K_{\exp }\right)$ and predicted value $\left(K_{\text {pre }}\right)$ of the saturated hydraulic conductivity as determined by Equation (21).

The first equation (i.e., Equation (18)) was obtained by examining the possible correlations between the $K_{\exp }$ values and a certain index property of the different investigated soils. From this research, it was found that the parameter that most influences hydraulic conductivity is $C_{F}$ and the best correlation was found through a power function as shown in Figure 6. This strong correlation between the clay content and the hydraulic conductivity, through a power function, was also suggested by [19], anyway the strong dependence to this parameter can be found in the equations proposed by the authors of $[20,25,26]$ for hydraulic conductivity prediction. 


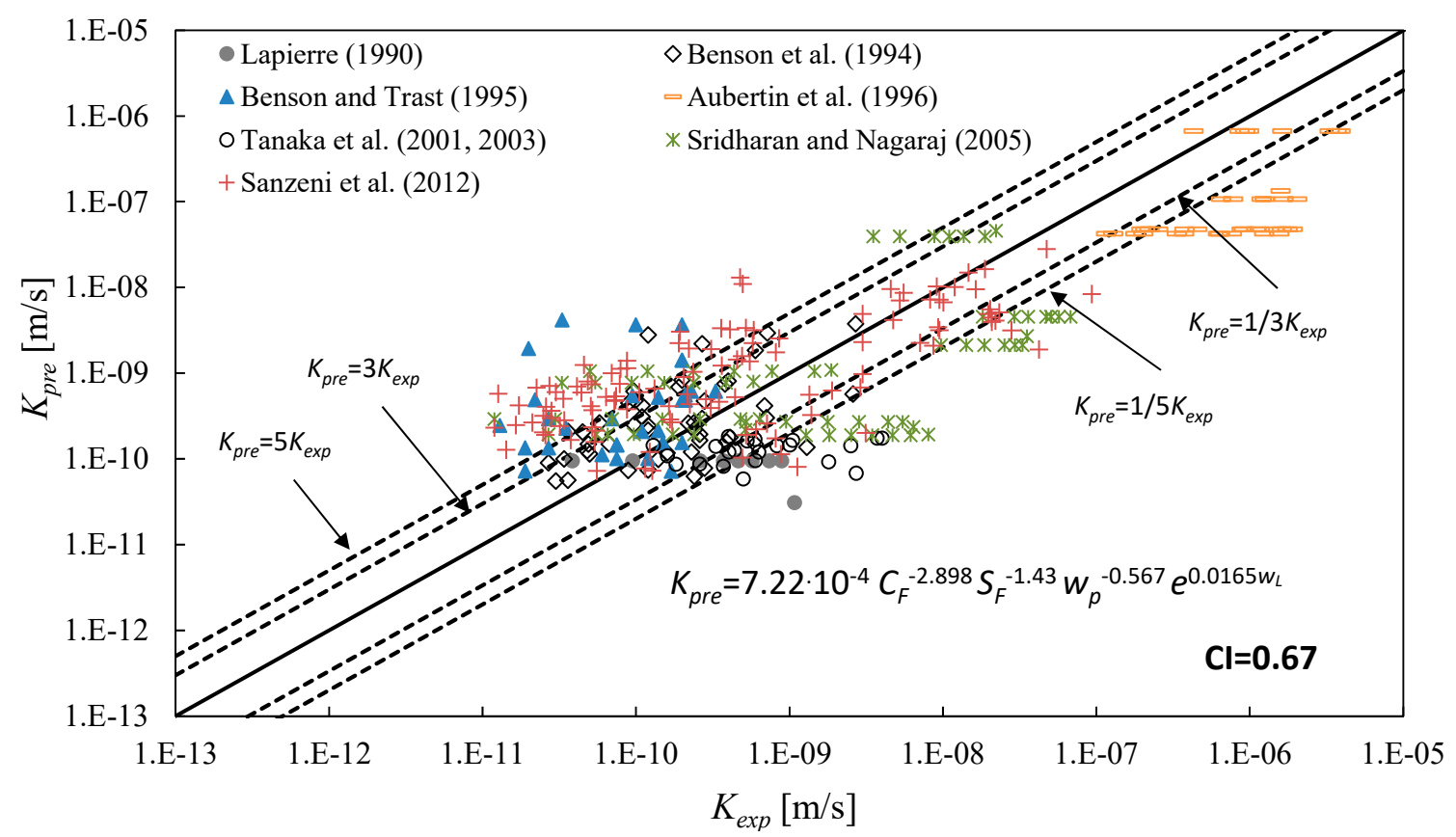

Figure 5. Experimental $\left(K_{\text {exp }}\right)$ and predicted value $\left(K_{\text {pre }}\right)$ of the saturated hydraulic conductivity as determined by Equation (22).

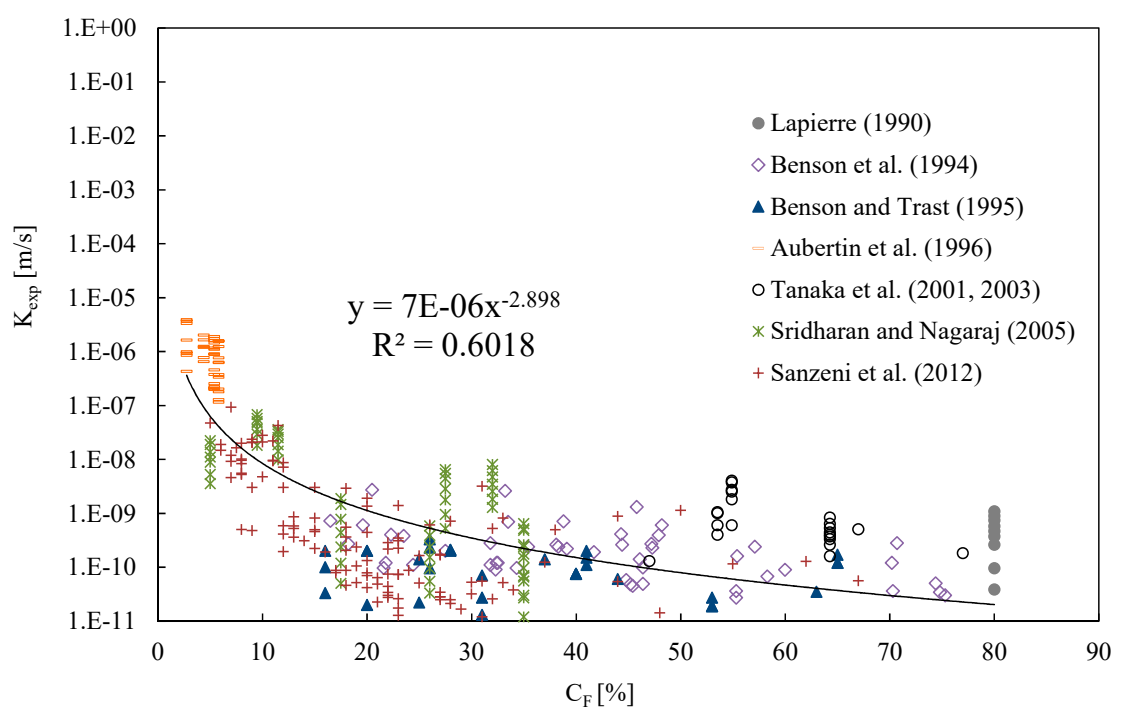

Figure 6. Experimental hydraulic conductivity $\left(\mathrm{K}_{\exp }\right)$ versus $C_{F}$.

The second parameter among those investigated (such as $n, I_{P}, w_{p}, w_{L}$, and $S_{F}$ ), which added to Equation (18) allows to significantly approach the experimental value of $K_{s a t}$ with the predicted one, is the void ratio. Most of the predictive models present in literature consider the variable $e$ in their formulation (i.e., Equations (1),(3),(4),(6),(7),(9),(12)). This variable allows to correctly differentiate the permeability of the same specimens having different values of $e$ (e.g., soils tested in $[17,24,28,29])$.

Starting from Equation (19), Equation (20) was obtained adding $w_{p}$ contribution. The plastic limit $w_{p}$ is the parameter that allows, better than $w_{L}$ and $I_{p}$, to improve the previous correlation between $K_{\text {pre }}$ and $K_{\text {exp }}$ especially for sandy silts of low plasticity for which the $K_{\text {sat }}$ values predicted by the previous equations (i.e., Equations (18) and (19)) were slightly underestimated. This parameter is not usually correlated to hydraulic conductivity in the predictive methods present in literature (only Equation (3) contains this parameter) where the parameters $w_{L}$ and $I_{p}$ are more common (see Equations 
$(2),(4),(6),(7),(12))$. For clayey soils the dependence of $K_{s a t}$ to $w_{L}$ is usually expressed by means of the specific surface (e.g., Equations (1) and (9)) through Equation (10).

Finally, starting from Equation (20), Equation (21) was obtained by adding the silt content $S_{F}$ a parameter that is not usual in literature predictive equations, which allows obtaining a more accurate estimate of $K_{\text {sat }}$. Equation (21) has the main advantage to take into account most of the variables influencing hydraulic conductivity, with respect to the correlations existing in literature that consider a lower number of variables (see Equations (2),(3),(4),(6),(7),(9),(11),(12)).

The variables considered in Equation (21) provide information about the grain size distribution (by means of $C_{F}$, and $S_{F}$ ), the mineralogical composition (by means of $w_{p}$ ) of the investigated soil as well as the void ratio $(e)$. The model does not account only for anisotropic behavior and permeant characteristics (only water as permeant liquid).

As expected, Equation (21) suggests that an increase of $C_{F}, w_{p}$, and $S_{F}$ values corresponds to an hydraulic conductivity decrease, whereas an increase of $e$ results in an increase of hydraulic conductivity.

According to the results obtained by the application of the five equations, proposed in this study, it can be observed that parameters referred to GSDC and the porosity or void ratio of soil greatly influence hydraulic conductivity as also observed by [37]. In fact, the method proposed by the authors (Equation (21)) show the best predictive capacity among the five proposed equations.

The different methods summarized in Table 1 were applied, under the conditions imposed by each author, to the soils shown in Table 2 that refers to the laboratory permeability tests database. In particular, Equation (2) was not applied for sandy silts soils; Equation (3), valid for remolded clay, was applied for specimens investigated by [17] and negative values of $K_{\text {pre }}$ were eliminated; the Equation (6) was applied only for soils having a value of $w_{L}$ greater than $50 \%$; the Equation (7) was not applied for soils having $w_{\mathrm{L}}$ lower than $20 \%$; the equation 9 was not applied for sandy silts soils (i.e., soils investigated by [27]) and for soils having $w_{\mathrm{L}}$ greater than $110 \%$; the Equations (4) and (12) were not applied to the created database since these methods are valid within a particular category of soils as shown in Table 1. The performance of these methods is shown in Figure 7.

The method of [18] (Equation (6), Figure 7c) shows a poor correlation and in particular underestimates the experimental values of $K_{\text {sat }}$ as also observed by [1]. Additionally, the method of [19] (Equation (11)) shows a poor correlation and in particular, it overestimates the experimental values of $K_{\text {sat }}$ (Figure 7f). The correlation improves with the method proposed by [14] and [15] (Equation (3), Figure $7 \mathrm{~b}$ ) but sometimes overestimates the experimental value of $K_{\text {sat }}$ as also observed by [1]. The method proposed by [8] (Equation (9), Figure 7e) and by [13] (Equation (2), Figure 7a) shows a poor correlation for soils having hydraulic conductivity greater than $10^{-9} \mathrm{~m} / \mathrm{s}$. The method proposed by [10] (Equation (7)) shows a good predictive capacity but underestimates the hydraulic conductivity for soils having $K_{\text {sat }}$ values greater than $10^{-8} \mathrm{~m} / \mathrm{s}$ (Figure $7 \mathrm{~d}$ ).

The method that shows the best correlation between the predicted and experimental values of $K_{s a t}$ is the method proposed by [21] (Equations (1) and (13)) as can be observed in Figure 7g and from the $C I$ value equal to 0.477 . This method, as previously described, consists of the application of Kozeny-Carman formulation (Equations (1) and the application of Equations (13) for the determination of the specific surface area of the plastic soil fraction. The method takes into account most of the variables influencing hydraulic conductivity: the grain size distribution of soil, the specific surface (which is linked to $w_{L}$ for plastic soils and therefore to the mineralogical composition), and porosity $(n)$. In this method, the amount of particles with a diameter less than $2 \mu \mathrm{m}$ greatly influences the hydraulic conductivity of plastic soils. As also pointed out by [21], their method is able to predict $K_{\text {sat }}$ for a wide range of soils having hydraulic conductivity values ranging from $10^{-11}$ to $5 \times 10^{-6} \mathrm{~m} / \mathrm{s}$, in fact this method underestimates hydraulic conductivity of soils having $K_{\text {sat }}$ values higher than about $10^{-6} \mathrm{~m} / \mathrm{s}$.

Equations (19)-(21) $(\mathrm{CI} \leq 0.46)$ allow obtaining an estimate of $K_{\text {sat }}$ slightly more accurate than that obtained by the application of the method proposed by [10] and by [21,22]. In particular, Equation (22), that considers only parameters obtained by economic and routine classification tests, provides predictive capacity slightly better than Equations (7) that needs $e$ value. 
The range of validity of the proposed equations includes soils having low, medium, and high plasticity and provides an accurate estimate of $K_{s a t}$ for soils having a wide range of values of soil index properties: $I_{P}$ between $2 \%$ and $71 \%, w_{L}$ between $17.5 \%$ and $119 \%, C_{F}$ between $2.7 \%$ and $80 \%$, and $S_{F}$ between $16 \%$ and $88 \%$.
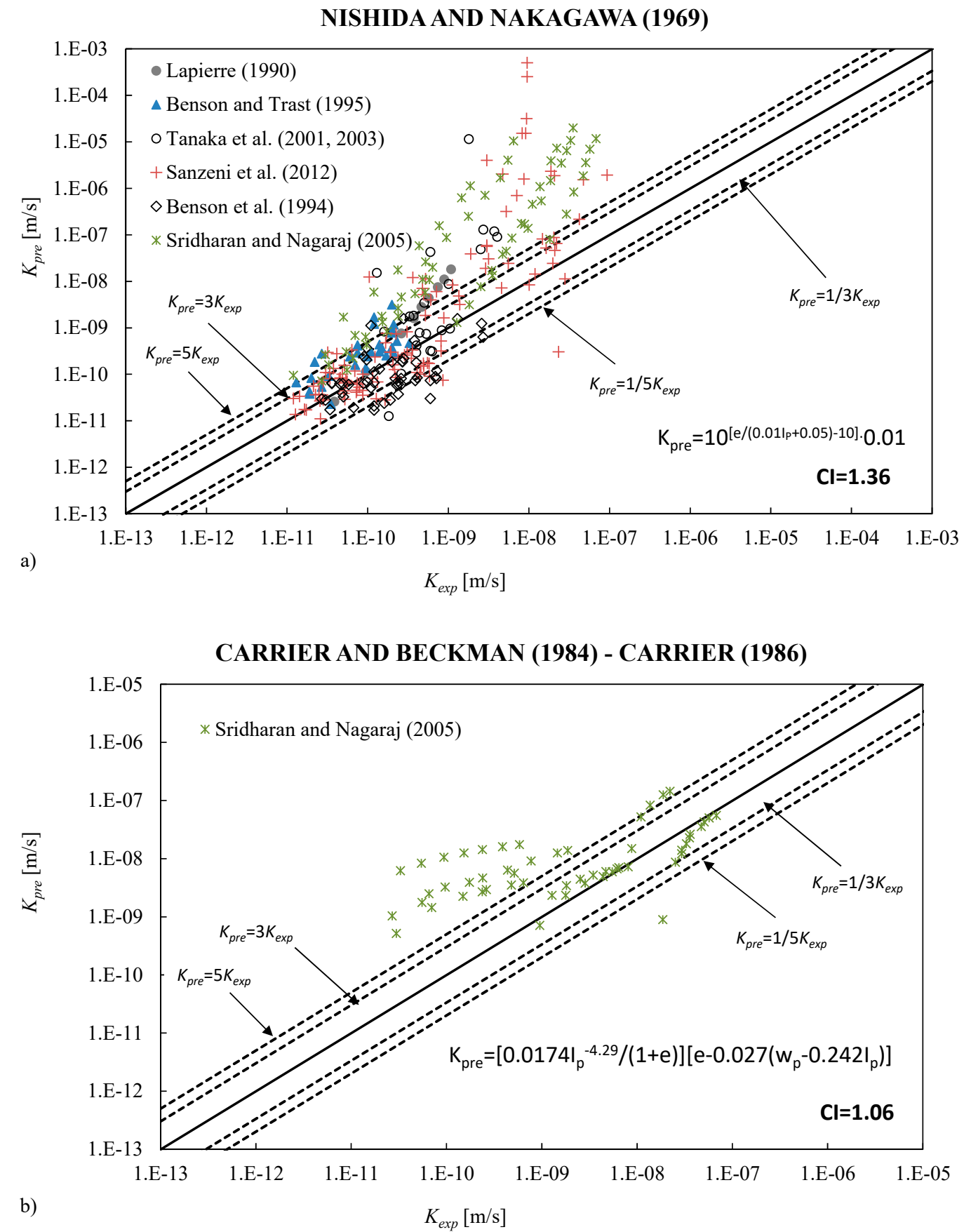

Figure 7. Cont. 


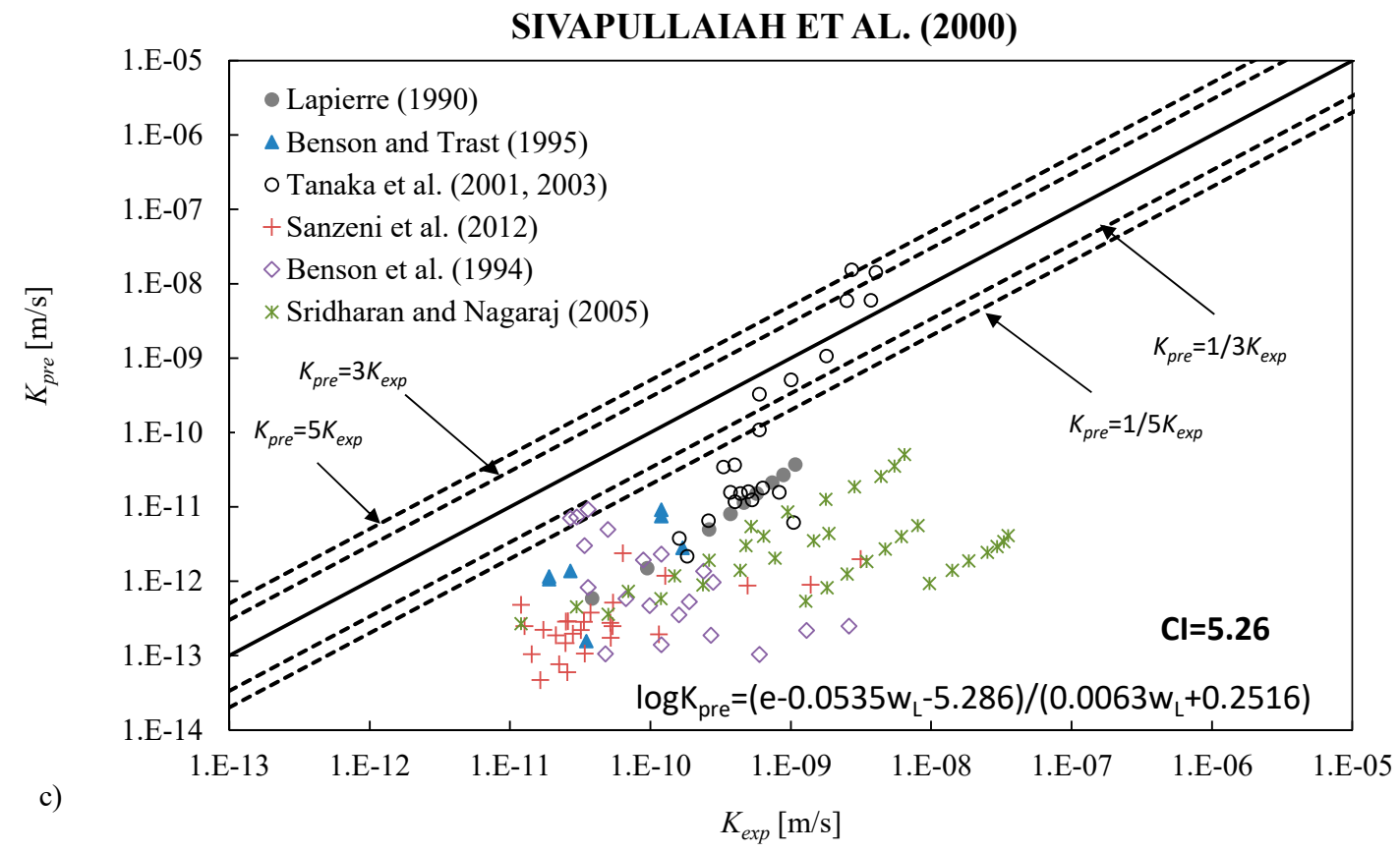

MBONIMPA ET AL. (2002)

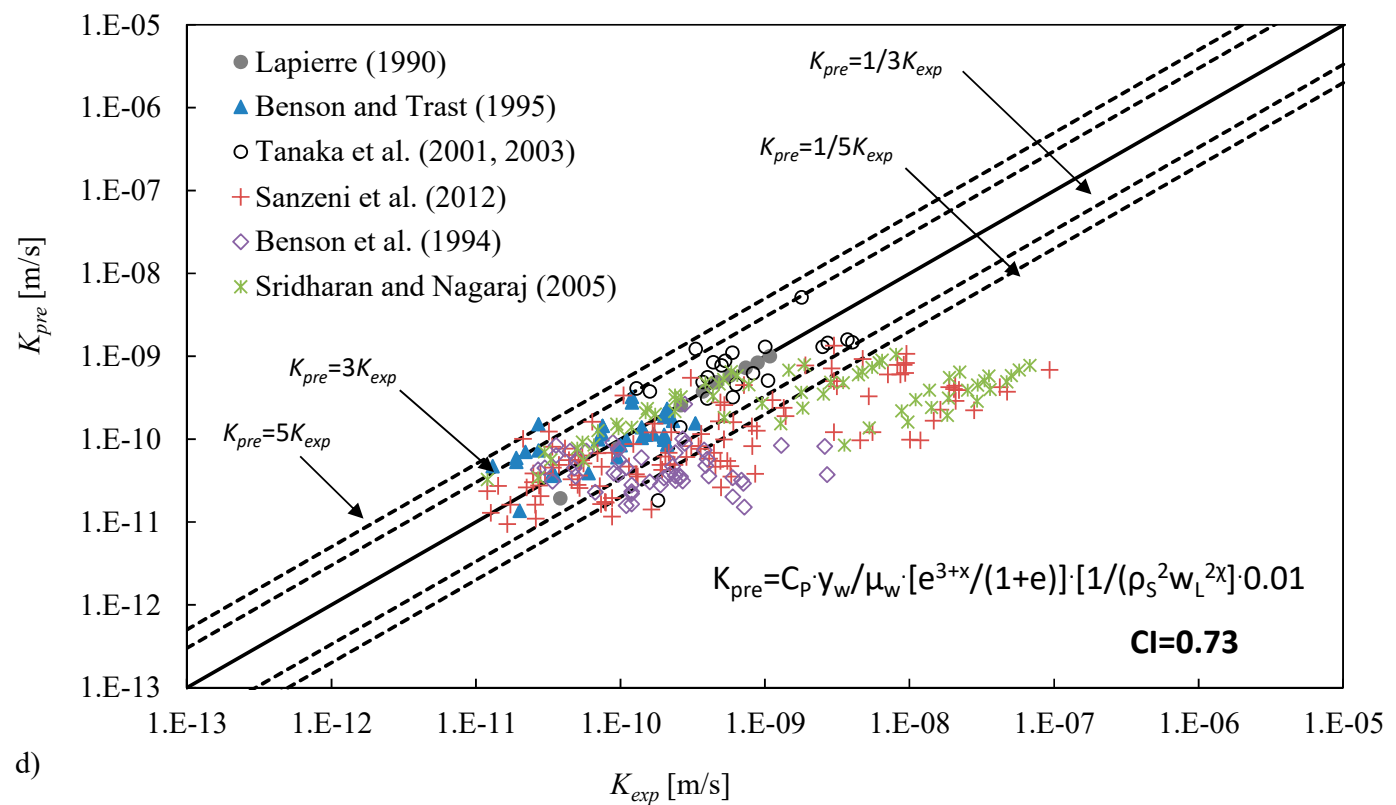

Figure 7. Cont. 
CHAPUIS AND AUBERTIN (2003)

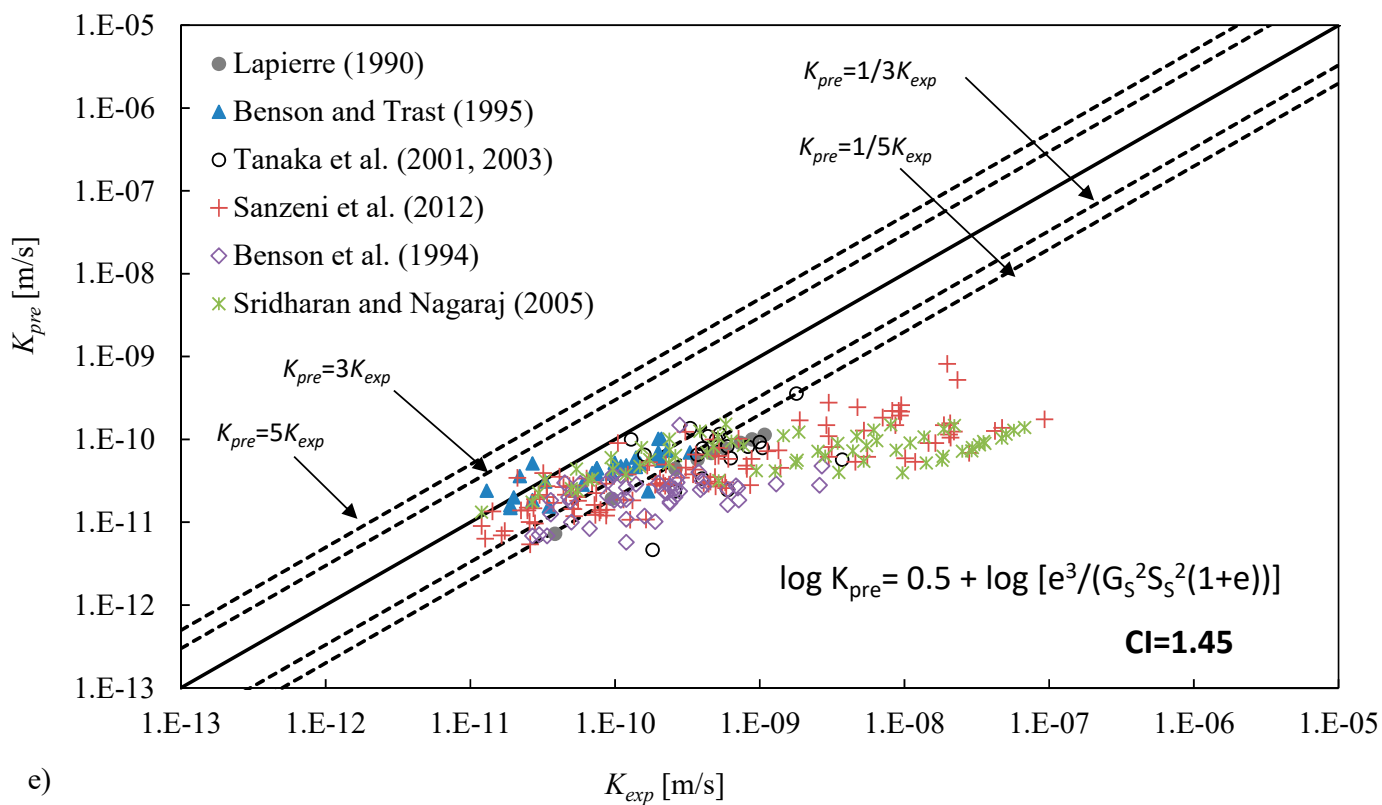

SHEVNIN ET AL. (2006)

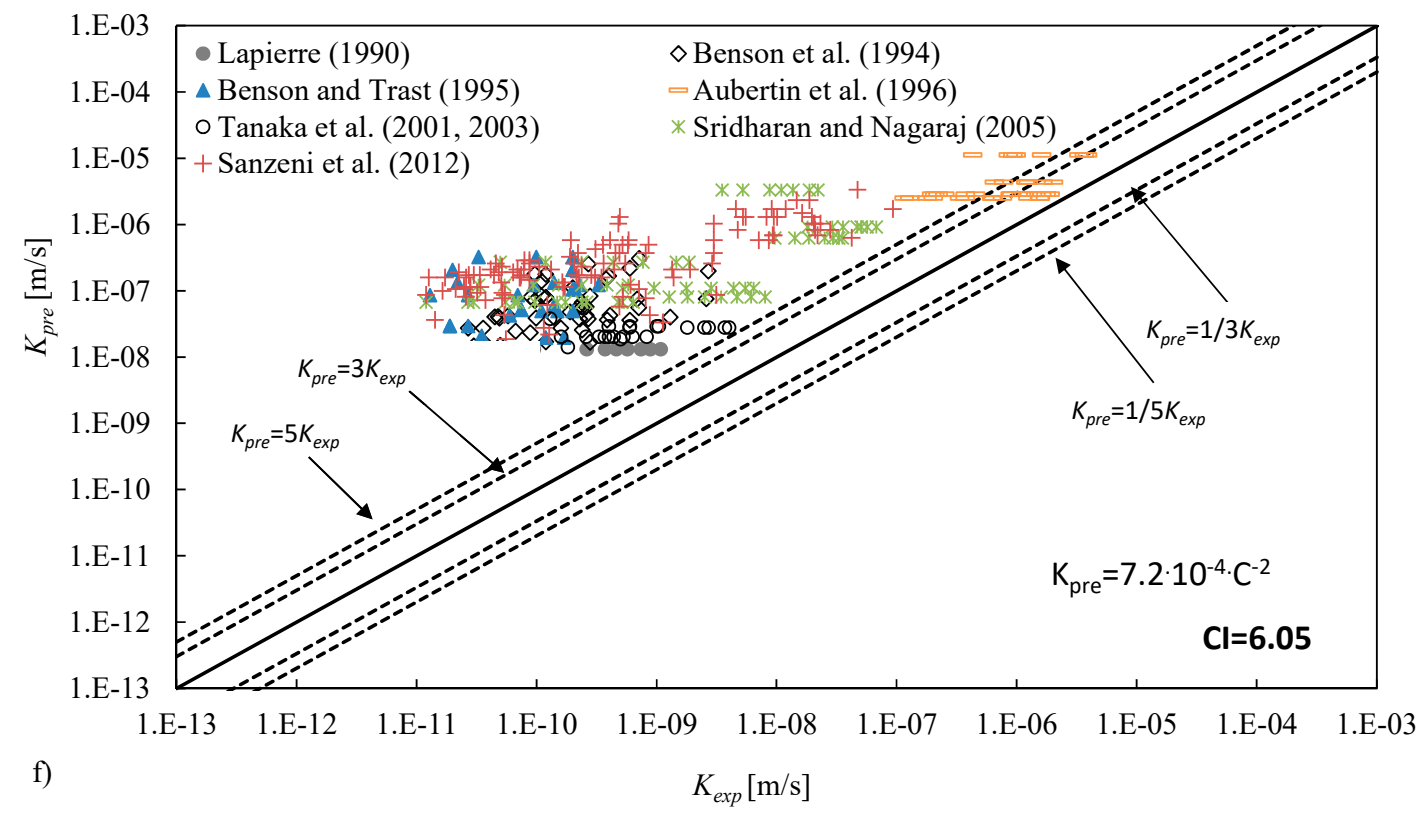

Figure 7. Cont. 
SANZENI ET AL. (2012)

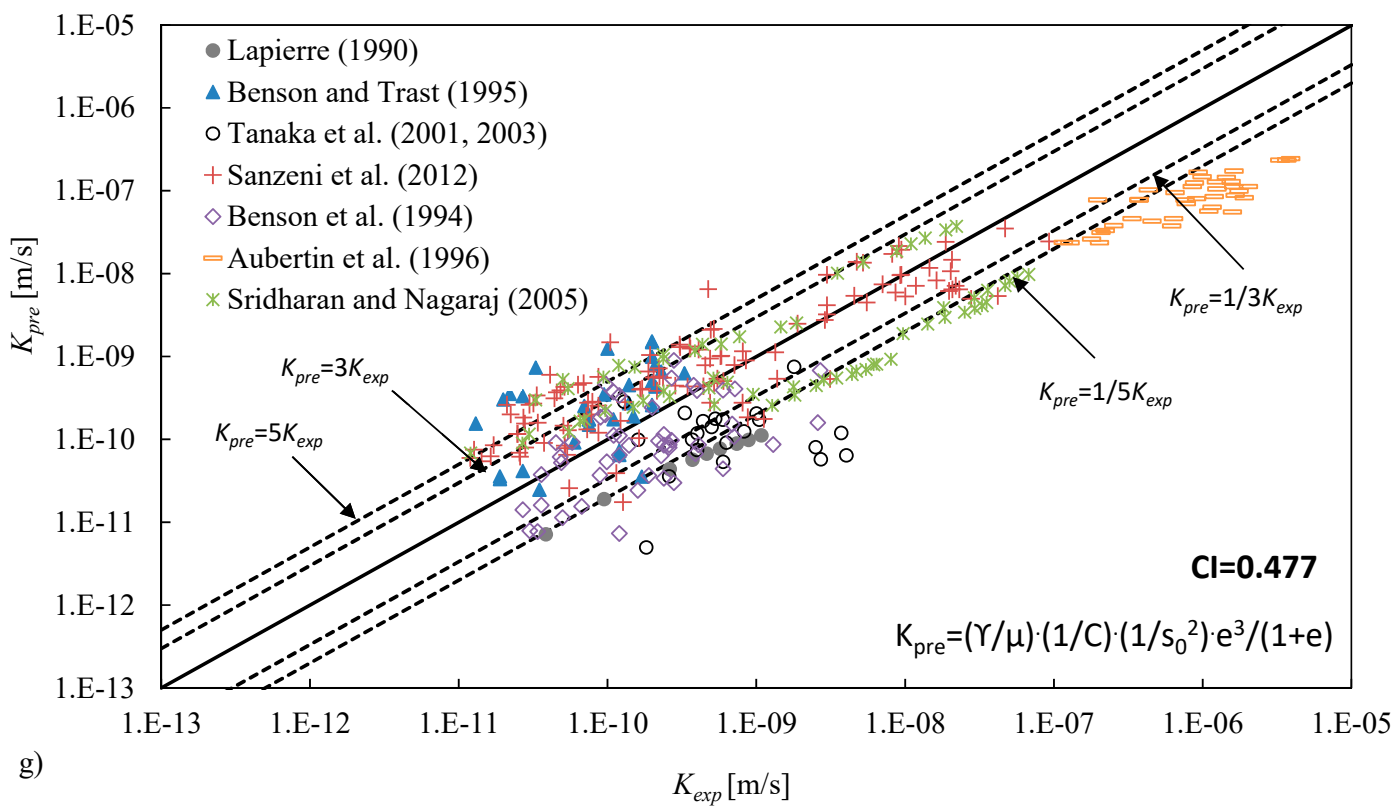

Figure 7. Experimental $\left(K_{\text {exp }}\right)$ and predicted value $\left(K_{\text {pre }}\right)$ of the saturated hydraulic conductivity as determined by (a) Equation (2), (b) Equation (3), (c) Equation (6), (d) Equation (7), (e) Equation (9), (f) Equation (11), and (g) Equations (1) and (13).

\section{Conclusions}

In this paper, new equations for the saturated hydraulic conductivity $\left(K_{s a t}\right)$ prediction in clayey soils and clayey or silty sand were developed.

The equations were derived by empirical correlations using a great and reliable number of experimental data (No. 329) taken from literature [17,21,24-29] and related to the saturated hydraulic conductivity, grain size distribution curve, porosity or void ratio, and consistency limits of different soils. Five equations were developed; each one correlates the hydraulic conductivity with one or more geotechnical parameters.

The first equation considers the contribution of clay content $\left(C_{F}\right)$, the second one adds the contribution of void ratio $(e)$, the third adds the contribution of plastic limit $\left(w_{p}\right)$, and the fourth adds the contribution of silt content $\left(S_{F}\right)$. The correlation between the experimental and predicted values of hydraulic conductivity increases with the number of parameters considered in the equation. In particular, among these variables, $C_{F}$ and $e$ are the parameters that greatly influence the hydraulic conductivity value.

A fifth equation, which considers only parameters obtained by economic and routine classification tests (i.e., $C_{F}, S_{F}, w_{p}$, and the limit liquid $w_{L}$ ), is also proposed. The exclusion of the void ratio provides a less accurate prediction of the hydraulic conductivity compared to the fourth proposed equation that is able to estimate $K_{\text {sat }}$ value in the range between $1 / 5$ and 5 times the experimental value of $K_{\text {sat }}$.

The proposed method is able to predict $K_{\text {sat }}$ of fine grained and plastic soils for a range of values (from $1.2 \times 10^{-11}$ to $3.9 \times 10^{-6} \mathrm{~m} / \mathrm{s}$ ) larger than that considered by most of the literature methods.

The proposed equations can be very useful in different situations as modelling study or during a screening phase in order to restrict, for economic reasons and of time, the number of field or laboratory permeability tests.

Author Contributions: Conceptualization, N.M.; Formal analysis, S.B., D.I. and N.M.; Methodology, S.B., D.I. and N.M.; Supervision, N.M.; Validation, S.B., D.I. and N.M.; Writing - original draft, S.B. and N.M. All authors have read and agreed to the published version of the manuscript.

Funding: This research received no external funding. 
Conflicts of Interest: The authors declare no conflict of interest.

\section{References}

1. Chapuis, R.P. Predicting the saturated hydraulic conductivity of soils: A review. Bull. Eng. Geol. Environ. 2012, 71, 401-434. [CrossRef]

2. Shepard, J.S. Using a Fractal Model to Compute the Hydraulic Conductivity Function. Soil Sci. Soc. Am. J. 1993, 57, 300-306. [CrossRef]

3. Giménez, D.; Perfect, E.; Rawls, W.J.; Pachepsky, Y. Fractal models for predicting soil hydraulic properties: A review. Eng. Geol. 1997, 48, 161-183. [CrossRef]

4. Yang, H.; Khoshghalb, A.; Russell, A.R. Fractal-based estimation of hydraulic conductivity from soil-water characteristic curves considering hysteresis. Geotech. Lett. 2014, 4, 1-10. [CrossRef]

5. Carman, P.C. Permeability of saturated sands, soils and clays. J. Agric. Sci. 1939, 29, 262-273. [CrossRef]

6. Fair, G.M.; Hatch, L.P. Fundamental Factors Governing the Streamline Flow of Water Through Sand. J. Am. Water Works Assoc. 1933, 25, 1551-1565. [CrossRef]

7. Chapuis, R.; Légaré, P.-P. A Simple Method for Determining the Surface Area of Fine Aggregates and Fillers in Bituminous Mixtures. In Effects of Aggregates and Mineral Fillers on Asphalt Mixture Performance; ASTM International: West Conshohocken, PA, USA, 1992; pp. 177-186.

8. Chapuis, R.P.; Aubertin, M. Predicting the Coefficient Permeability of Soils Using the Kozeny-Carman équation. Available online: https://www.researchgate.net/publication/228699587_Predicting_the_coefficient_ of_permeability_of_soils_using_the_Kozeny-Carman_equation (accessed on 7 September 2020).

9. Muhunthan, B. Liquid limit and surface area of clays. Geotechnique 1991, 41, 135-138. [CrossRef]

10. Mbonimpa, M.; Aubertin, M.; Chapuis, R.P.; Bussière, B. Practical pedotransfer functions for estimating the saturated hydraulic conductivity. Geotech. Geol. Eng. 2002, 20, 235-259. [CrossRef]

11. Chapuis, R.P.; Aubertin, M. Discussion of "Influence of relative compaction on the hydraulic conductivity of completely decomposed granite in Hong Kong". Can. Geotech. J. 2010, 47, 704-707. [CrossRef]

12. Mitchell, J.; Hooper, D.; Campenella, R. Permeability of Compacted Clay. J. Soil Mech. Found. Div. 1965, 91, 41-65.

13. Nishida, Y.; Nakagawa, S. Water permeability and plastic index of soils. In Proceedings of the IASH-UNESCO Symposium Tokyo, Tokyo, Japan, September 1969; pp. 573-578.

14. Carrier, W.D.; Beckman, J.F. Correlations between index tests and the properties of remoulded clays. Geotechnique 1984, 34, 211-228. [CrossRef]

15. Carrier, W.D. Discussion: Consolidation parameters derived from index tests. Géotechnique 1986, 36, $291-292$. [CrossRef]

16. Samarasinghe, A.M.; Huang, Y.H.; Drnevich, V.P. Permeability and consolidation of normally consolidated soils. J. Geotech. Eng. Div. 1982, 108, 835-850. [CrossRef]

17. Sridharan, A.; Nagaraj, H.B. Hydraulic conductivity of remolded fine-grained soils versus index properties. Geotech. Geol. Eng. 2005, 23, 43-60. [CrossRef]

18. Sivapullaiah, P.V.; Sridharan, A.; Stalin, V.K. Hydraulic conductivity of bentonite-sand mixtures. Can. Geotech. J. 2000, 37, 406-413. [CrossRef]

19. Shevnin, V.; Delgado-Rodríguez, O.; Mousatov, A.; Ryjov, A. Estimation of hydraulic conductivity on clay content in soil determined from resistivity data. Geofis. Int. 2006, 45, 195-207. [CrossRef]

20. Dolinar, B. Predicting the hydraulic conductivity of saturated clays using plasticity-value correlations. Appl. Clay Sci. 2009, 45, 90-94. [CrossRef]

21. Sanzeni, A.; Grazioli, D.; Colleselli, F. Superficie specifica e applicabilità della formula di Kozeny-Carman per la stima della conducibilità idraulica delle terre. Riv. Ital. di Geotec. 2012, 2, $42-43$.

22. Sanzeni, A.; Colleselli, F.; Grazioli, D. Specific Surface and Hydraulic Conductivity of Fine-Grained Soils. J. Geotech. Geoenvironmental Eng. 2013, 139, 1828-1832. [CrossRef]

23. Carrier, W.D. Goodbye, Hazen; hello, Kozeny-Carman. J. Geotech. Geoenvironmental Eng. 2003, 129, $1054-1056$. [CrossRef]

24. Lapierre, C.; Leroueil, S.; Locat, J. Mercury intrusion and permeability of Louiseville clay. Can. Geotech. J. 1990, 27, 761-773. [CrossRef] 
25. Benson, C.H.; Zhai, H.; Wang, X. Estimating Hydraulic Conductivity of Compacted Clay Liners. J. Geotech. Eng. 1994, 120, 366-387. [CrossRef]

26. Benson, C.H.; Trast, J.M. Hydraulic conductivity of thirteen compacted clays. Clays Clay Miner. 1995, 43, 669-681. [CrossRef]

27. Aubertin, M.; Bussière, B.; Chapuis, R.P. Hydraulic conductivity of homogenized tailings from hard rock mines. Can. Geotech. J. 1996, 33, 470-482. [CrossRef]

28. Tanaka, H.; Locat, J.; Shibuya, S.; Soon, T.T.; Shiwakoti, D.R. Characterization of Singapore, Bangkok, and Ariake clays. Can. Geotech. J. 2001, 38, 378-400. [CrossRef]

29. Tanaka, H.; Shiwakoti, D.R.; Omukai, N.; Rito, F.; Locat, J.; Tanaka, M. Pore Size Distribution of Clayey Soils Measured by Mercury Intrusion Porosimetry and its Relation to Hydraulic Conductivity. Soils Found. 2003, 43, 63-73. [CrossRef]

30. Chapuis, R.P. Similarity of internal stability criteria for granular soils. Can. Geotech. J. 1992, 29, 711-713. [CrossRef]

31. Moraci, N.; Mandaglio, M.C.; Ielo, D. A new theoretical method to evaluate the internal stability of granular soils. Can. Geotech. J. 2012, 49, 45-58. [CrossRef]

32. Kezdi, A. Increase of Protective Capacity of Flood Control Dikes; Technical Report; Department of Geotechnics, Technical University of Budapest: Budapest, Hungary, 1969.

33. Sherard, J.L. SINKHOLES IN DAMS OF COARSE, BROADLY GRADED SOILS. In Proceedings of the 13th International Congress on Large Dams, Transactions, New Delhi, India, 29 October-2 November 1979; pp. 25-35.

34. Kenney, T.C.; Lau, D. Internal stability of granular filters. Can. Geotech. J. 1985, 22, 215-225. [CrossRef]

35. Moraci, N.; Mandaglio, M.C.; Ielo, D. Analysis of the internal stability of granular soils using different methods. Can. Geotech. J. 2014, 51, 1063-1072. [CrossRef]

36. Moraci, N.; Mandaglio, M.C.; Ielo, D. Reply to the discussion by Ni et al. on "Analysis of the internal stability of granular soils using different methods". Can. Geotech. J. 2015, 52, 385-391. [CrossRef]

37. Chapuis, R.P. The 2000 R.M. Hardy lecture: Full-scale hydraulic performance of soil-bentonite and compacted clay liners. Can. Geotech. J. 2002, 39, 417-439. [CrossRef]

(C) 2020 by the authors. Licensee MDPI, Basel, Switzerland. This article is an open access article distributed under the terms and conditions of the Creative Commons Attribution (CC BY) license (http://creativecommons.org/licenses/by/4.0/). 